\title{
LIABILITY INSURANCE IN THE CONTEXT OF THE COVID-19 PANDEMIC
}

\section{Seguro de responsabilidad en el contexto de la pandemia COVID-19}

Kyriaki Noussia

University of Exeter, Law School (UK)

E-mail: k.noussia@exeter.ac.uk

The COVID-19 pandemic has meant that business and contractual relationships have been disrupted. The pandemic has also meant that there are legal liabilities owed to disruption, cancellations, or to the imposed halt of everyday life. We discuss force majeure and frustration in contract in cases where circumstances have changed due to unnatural events such as the COVID-19 pandemic and the impact of the pandemic on business interruption, and liability insurance. The scope of insurance coverage for catastrophic risks and the civil liability insurance as well as business interruption coverage are discussed and conclusions on the role of insurance in the COVID-19 pandemic are drawn, as the body of case law and the pandemic per se continues to sweep humanity in an unprecedented way.

La pandemia de COVID-19 ha significado la interrupción de las relaciones comerciales y contractuales. La pandemia también ha supuesto que surjan responsabilidades legales debidas a las interrupciones, cancelaciones o al cese impuesto a la vida cotidiana. En este articulo se analizan la fuerza mayor y la interrupción de contratos en casos donde las circunstancias ban cambiado debido a eventos no naturales como la pandemia de COVID-19 y el impacto que esta tiene en la interrupción de los negocios y seguro de responsabilidad. Se discute el alcance de la cobertura del seguro para riesgos catastróficos y el seguro de responsabilidad civil, asi como la cobertura de interrupción del negocio y se extraen conclusiones sobre el papel de los seguros en la pandemia COVID-19, ya que los casos y la pandemia per se continuan barriendo a la bumanidad de una manera sin precedentes.

legal liabilities; force majeure; insurance; COVID-19

responsabilidad legal; fuerza mayor; seguros; COVID-19

Key words

Received: 30/11/2020. Accepted: 09/12/2020

\section{Author}

(i) Abstract Dates 


\section{Introduction}

Coronaviruses have always existed in our environment. However in 2019, a new "novel coronavirus", "dubbed" as COVID-19 has been identified and has led to a worldwide pandemic with huge healthcare, medical as well as financial impacts, for humans and their health as well as for the society. As waves and mutations of this virus have kept coming and going in different pace and time lengths in the different parts of the world during 2019 and 2020 so far, different governments around the world have declared lockdown measures in an effort to restrain and halt the virus's spread, whilst multiple efforts to create vaccines for it continue.

Governmental shut-down of businesses for intended periods of time so as to contain the virus has meant that companies have been unable to perform their duties and obligations under various contracts. In addition, insurance mechanisms that have been in place, such as e.g. business interruption policies, have triggered claims, and business have argued the occurrence of "force majeure" both in relation to their commercial and insurance contracts as they have wanted to justify the temporary suspension of their performance obligations under contracts and protect themselves against failures to perform as per such commercial contracts, as well as claim from their insurers on the basis of their general, liability or business interruption insurance policies.

With regards to commercial contracts, whether COVID-19 constitutes a "force majeure" event depends on the definition of "force majeure" in each specific contract and the biggest and better certainty and justification for a "force majeure" operation will arise from a detailed "force majeure" clause. In commercial contracts "force majeure" can be described and be defined or not, and where it may contain examples it can include "epidemics", "pandemics" or "acts of government" which can classify as "acts of God" or exclude such terms.

In the context of COVID-19 if such terms are included a party may argue that the pandemic is an "act of God" or that it constitutes "force majeure", as well as argue that government restrictive operational measures (e.g. "lockdowns") are "acts of government" equal to "force majeure" in effect.

Continental law is allowing commercial impracticability to justify court adjustment of contractual performance obligations and rights on the basis of the justification of a "force majeure", in extreme cases such as pandemics or during or after extreme economic dislocation, like World Wars. Such a court-triggered adjustment of the contract to the new circumstances, is allowed as per the well-established obligation of good faith in the civil law of all continental jurisdictions.

For insurance contracts, cover will be available under business interruption and contingent business interruption insurance policies, or general liability insurance cover for third party claims of property damage or bodily injury from the spread of COVID-19 due to some act taken or not taken by the insured company, or for expenses incurred aa a result of government-mandated shutdowns.

This paper discusses the scope of insurance coverage and the interpretation of the term "force majeure" by courts in the body of current case law and in relation to future cases and the arising liability for catastrophic risks and draws conclusions on the role of insurance in the COVID-19 pandemic era. 


\section{Force majeure, frustration and the principle of changed circumstances in contract law as a way to circumvent the consequences of non-performance of the contract}

Where a party relies on a force majeure clause, compensation depends on the wording available and the cases for such a compensation may include a temporary suspension of the contract during the period when the force majeure event persists; the extinguishment of any liability arising from the non-performance and/or delay; the right of either or both of the parties to terminate the contract; or the automatic discharge of the contract which brings to end the obligations of the parties (Hewitson, 2020, p. 119).

The question which arises is whether, in the absence of a force majeure clause in a contract, or if there is such a clause but it fails to correspond to the compensation of the party in suffering, the contract could be frustrated. A contract may be frustrated where an event occurs after the contract has been exchanged that makes it physically or commercially impossible to complete the contract. Alternatively, the contract could be frustrated where the obligations become significantly different from the ones that were agreed when the contract was entered into ${ }^{1}$.

The doctrine of frustration was established in Taylor $v$ Caldwell $^{2}$ as an exception to the general rule that if performance of a contract becomes more difficult or even impossible, the party who fails to perform the contract is liable to the other in damages. This doctrine aims to avoid injustice where neither party has done anything wrong and it is not their fault that the contract is now impossible to carry out ${ }^{3}$.

In practice it is difficult to establish that a frustrating event has occurred and frustration is listed as encompassing events such as, where an event occurs after the contract has been formed, neither party is at fault, where the event is beyond what was contemplated by the parties on entering into the contract and is so fundamental that it alters the contract and the event renders performance of the contract impossible, illegal or radically different from that contemplated by the parties at the time of the contract, where the subject matter of the contract is unavailable, where a subsequent change in the law or circumstances which makes performance of the contract illegal, for example, the outbreak of war or a pandemic, or where performance of the contract would impose a burden on one party which is radically different from that contemplated at the time of entering into the contract, without rendering performance actually impossible or where there is an unexpected delay in the performance of the contract as a result of an unexpected event or change in circumstances and the delay is so abnormal

1 Denny Mott EF Dickson Ltd v James B Fraser EF Co Ltd [1944] A.C. 265; [1944] 1 All E.R. 678; Fibrosa Spolka Akcyjna v Fairbairn Lawson Combe Barbour Ltd [1943] A.C. 32; [1942] 2 All E.R. 122; Tsakiroglou छ Co Ltd v Noblee Thorl GmbH [1962] A.C. 93; [1961] 2 W.L.R. 633; Pioneer Shipping Ltd v BTP Tioxide Ltd (The Nema) (No. 2) [1982] A.C. 724; [1981] 3 W.L.R. 292; Hewitson (2020, pp. 119-121).

2 Taylorv Caldwell 122 E.R. 309; (1863) 3 B. E'S. 826.

3 Denny Mott Eं Dickson Ltd v James B Fraser E Co Ltd [1944] A.C. 265; [1944] 1 All E.R. 678; Fibrosa Spolka Akcyjna v Fairbairn Lawson Combe Barbour Ltd [1943] A.C. 32; [1942] 2 All E.R. 122; Tsakiroglou छ Co Ltd v Noblee Thorl GmbH [1962] A.C. 93; [1961] 2 W.L.R. 633; Pioneer Shipping Ltd v BTP Tioxide Ltd (The Nema) (No. 2) [1982] A.C. 724; [1981] 3 W.L.R. 292; Hewitson (2020, pp. 119-121). 
that it falls outside what the parties could have contemplated at the time they entered into the contract ${ }^{4}$.

Under English law, early cases, as stated above, allowed an excuse from performance obligations through the insertion of an "implied condition" regarding the continued existence or future occurrence of a state of affairs ${ }^{5}$. Later on, as case law evolved, the true rationale of frustration was depicted, and the body of case law was very strict in its interpretation. Hence, it did not formulate a general rule to allow frustration to operate altogether and discharge parties from their obligations, but a granted and justified contractual non-performance was decided on a case-by-case basis ${ }^{6}$, as non-excuse of performance was in line with the argument that under

English law of contract commercial impracticability of performance cannot serve as an excuse.

Hence, the scope of application of the doctrine of frustration under English law is very limited, and there are strict consequences where a contract is found to have been frustrated (Nottage, 2007, pp. 385-387). Both in the USA and in the continental law regimes, a departure from the general rule allowing contract frustration when extreme circumstances justify it, is acceptable, as a contracting party is not liable for non-attributable performance due to an act of God or any event beyond his control' ${ }^{7}$.

If the meaning of the force majeure clause is unclear, a court will follow the usual rules of contractual construction and will likely take into account the following: a) the words should be given their natural and ordinary meaning. In Coastal (Bermuda) Petroleum Ltd v VTT Vulcan Petroleum SA (No 2) (The Marine Star) ${ }^{8}$ the Court of Appeal allowed the appeal, holding that the judge had erred in seeking out and relying on the parties' "general intentions". The proper approach to a force majeure clause is to interpret it by reference to the words the parties had actually used in the contract. The court will also consider the meaning of the clause in the context of the remainder of the contract. If the contract specifies that performance must have been "prevented" by the force majeure event, performance must have become physically or legally impossible, not merely more difficult or unprofitable (Irvine, 2020, pp. 156-157). Specified events such as "acts of God" may not necessarily be given the same meaning in another type of contract. However, an "act of God" will usually mean an event which is due to natural causes, without human intervention and may well not cover an evolving situation

4 Denny Mott $\Xi^{\circ}$ Dickson Ltd v James B Fraser $\Xi^{\circ}$ Co Ltd [1944] A.C. 265; [1944] 1 All E.R. 678; Fibrosa Spolka Akcyjna v Fairbairn Lawson Combe Barbour Ltd [1943] A.C. 32; [1942] 2 All E.R. 122; Tsakiroglou छ Co Ltdv Noblee Thorl GmbH [1962] A.C. 93; [1961] 2 W.L.R. 633; Pioneer Shipping Ltd v BTP Tioxide Ltd (The Nema) (No. 2) [1982] A.C. 724; [1981] 3 W.L.R. 292; Hewitson (2020, pp. 119-121).

5 Taylorv Caldwell, [1863] 122 Eng. Rep. 309, 312 (K.B.); Krell v Henry, [1903] 2 K.B. 740, 746.

6 Davis Contractors Ltd. v Fareham Urban Dist. Council, [1956] A.C. 696, 728 (H.L.); Denny, Mott Eं Dickson, Ltd. v James B. Fraser Eं Co., Ltd, [1944] A.C. 265, 275 (H.L.)

7 Eg. Article 415 of the Civil Code of Japan; Article 388 of the Greek Civil Code, Article 622 of the Greek Civil Procedure Code; Iijima (1994, pp. 127-129); Nottage (2007, pp. 385, 387); Stathopoulos (1998). 
like the pandemic. The High Court in Seadrill Ghana Operations Ltd v Tullow Ghana Ltd 9 ruled that the "force majeure event" must be the sole cause of a delay or failure to perform, relying upon Intertradex $v$ Lesieu $^{10}$.

However, if the contract specifies otherwise, the wording of the clause will take precedence. If a party is not willing and/or able to perform the contract in spite of the force majeure event, that party will not be able to rely on the force majeure clause to escape liability for that delay or failure to perform. Furthermore, any damages awarded for a breach caused by this failure to perform will be calculated as if the force majeure event had not happened, as per Classic Maritime Inc v Limbungan Makmur SDN BHD ${ }^{11}$.

The doctrine of changed circumstances is present in the law of continental jurisdictions and allows non-performance of the contract if a substantial change in circumstances, such as economic crisis after wars, affecting the basis of the contract has occurred. In Japan, the principle of change of circumstances was recognized towards the end of World War II and also afterwards. Under Greek law pursuant to the provision of article 388 of the Greek Civil Code allows parties to not be legally bound to perform under a contract which, due to unforeseen events that may have evolved into an extremely burdensome undertaking, as circumstances have changed drastically; and as a result of the change in circumstances to be able to invoke and argue that there is frustration of the contract. All this is in accordance with the principle of good faith, as elaborated in Greek contract law (Stathopoulos, 2020) and in the body of case law ${ }^{12}$. Article 388 of the Greek Civil Code sets also the need to satisfy a) the existence of a contract between the parties; b) the subsequent, unforeseen and extraordinary change of circumstances $^{13}$. These extraordinary grounds must affect events relating to what the parties expected so as to conclude the contract ${ }^{14}$.

\section{Business Interruption Insurance}

Business interruption insurance covers financial losses due to loss of revenue because of nonoperation. Such insurance is bought as a stand-alone cover or as part of a property policy. Proponents against the satisfaction of COVID-19 claims argued that no causation is proven as there is no damage to property as a result of the pandemic, and with no such damage to property the business interruption insurance claim falls short. However, in the context of

9 Seadrill Ghana Operations Ltd v Tullow Ghana Ltd [2018] EWHC 1640(Comm); [2019] 1 All E.R. (Comm) 34 .

10 Intertradex v Lesieur [1978] 2 Lloyd's Rep. 509.

11 Classic Maritime Inc v Limbungan Makmur SDN BHD [2019] EWCA Civ 1102; [2019] 4 All E.R. 1145; Irvine (2020).

12 Greek Supreme Court Judgment 16/1983, [1983] NoB 31.1368, Greek Supreme Court Judgment.

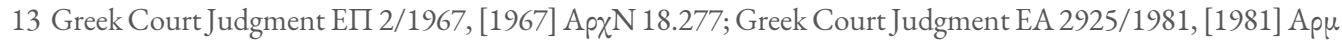
35.756; Greek Supreme Court Judgment A.П 1733/1986, [1986] NoB 35.1057.

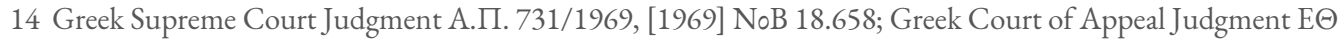
1680/1980, [1980] Apu 35.550; Stathopoulos (2020, p. 504); Greek Supreme Court Judgment А.П. 731/1969,

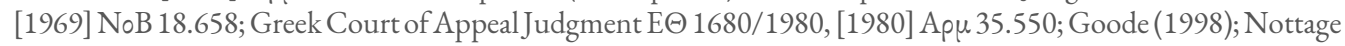
(2007, p. 416). 
COVID-19 claims for "damage to property" are justified if an order by a public authority has been made and the business interruption policy operates and provides coverage. The assured has to prove that he had some physical loss or damage to their property, however the changing circumstances may allow for the insurance coverage to be extended and expanded (Rupprecht, 2020, 26 ${ }^{\text {th }} \mathrm{March}$ ) or the mere existence of the virus in a location will constitute enough evidence of physical loss or damage.

Business interruption insurance policies, depending on their wording, might also cover for losses arising from expenses incurred for decontamination, some policies will provide coverage. A hurdle to overcome here is that of certain exclusions for viruses and/or bacteria, and if viruses are not covered then the business interruption policy will not operate, since COVID-19 is a virus and not a bacterium. Contingent business interruption insurance policies will allow "contingent" coverage, i.e. coverage for indirect losses such as losses from the interruption of the supply chain, so long that the damage incurred at the supplier's location has been the cause of the interruption. Also, some policy enhancements can expand coverage in some policies, (e.g. in the case of "lockdowns") will be available as civil authority insurance coverage in the form of a policy coverage extension ${ }^{15}$, or communicable or infectious disease coverage and notifiable disease coverage which provide insurance cover for losses from the pandemic without the need for physical damage to the property, or political risk or event insurance cover, which respectively provides business interruption cover for losses from foreign government actions or for financial losses from the cancellation of events as a result of the pandemic and certain government mandated closures.

In relation to property damage, commercial property damage insurance is generally intended to cover losses caused when property suffers "physical loss or damage". To recover, policyholders will likely need to demonstrate that they suffered some form of physical loss or damage to their property, as those terms are defined in their policies. How this language applies to the current crisis will surely be litigated in court. Insurers trying to avoid coverage will argue that policyholders' losses are not from physical loss or damage to property, like a building collapse or fire, but have non-physical causes - e.g., people staying home. Courts have held that contamination that attaches to the property, or that physically affects property so as to render it uninhabitable or unfit for its intended use, can constitute physical loss or damage. Similarly, some courts have found a physical loss to property when the air has been contaminated, making the building unfit for occupancy, or because of a strong odor that makes the property uninhabitable. Notably, New York City's March 16, 2020 Emergency Executive Order addressing the threat of COVID-19 expressly found that "the virus physically is causing property loss and damage". As policies differ and courts also do not uniformly interpret the relevant policy terms, policyholders must look at the specific policy portfolios they have, and the provisions in each of these policies. In business interruption as most business interruption policies require that the interruption is caused by loss or damage to property, an issue that likely will be litigated in this context is whether the suspected presence of the virus in a location, or even the fact that the location is unsafe for its intended use given restrictions on gatherings of people in a single location, might constitute physical loss or damage. Generally, business interruption policies provide that the policyholder must suspend operations because of covered peril before collecting its losses. Each of these is a defined term, hotly litigated based 
on the facts and circumstances of each individual case, and coverage often turns on the definition of these terms. The policy language is paramount. As of March 10, 2020, New York State requires insurers to (1) disclose certain information to regulators about their business interruption policies, and (2) make specific disclosures to policyholders about the scope of their insurance coverage. Claims for financial losses arising from any closure of a business will likely only be covered where such closure has been ordered by a public authority. Cover for Notifiable Diseases may be restricted insofar as the locality of discovery of the disease (that is, where the disease was discovered). Some policies provide cover where the Notifiable Disease occurs within the "vicinity" of an insured location. "Vicinity" will likely be a defined term in the policy wording. Most insured locations in the UK are able to rely on such wording, given the broad and rapid spread of the virus. An assured might also have an extension of cover for "Infectious Diseases" in their policy. This extension is likely to have a low sub-limit (that is, a financial limit), and there would probably be a higher limit under the Notifiable Diseases cover. At an early stage, it will be necessary for an insured to demonstrate that the downturn or cessation of business is a consequence of a covered cause or event. It is therefore important to consider what the precise cause is. Determination of the cause of the interruption may also be important for the purposes of any aggregation. Depending on policy wording, assureds may want to avoid all of their COVID-19 losses being aggregated as a "single" claim and may want to be able to make more than one such claims. Evidence of the amounts sought will include business income proven by previous management accounts and profit and loss accounts showing the turnover of the business. And other expenses such as additional costs incurred that are associated with dealing with the business interruption and consequential losses, such as additional temporary workers or third-party contractors, if permanent staff have been diagnosed with COVID-19 or forced to self-isolate, or claims preparation costs, contractual penalties, or public relations costs. Cyber liability coverage inside professional liability policies will also cover for losses from hackers and cyber risks (Rupprecht, 2020, 26 March)

Numerous claims for business interruption due to the pandemic have reached the courts in different jurisdictions. In the USA initially courts have rejected the COVID-19 business interruption claims. However, in April 2020, a court in Paris ordered AXA to pay two months revenue losses to a restaurant owner who was the policyholder of a business interruption insurance and had submitted a claim that had been rejected by his insurer (Pineau \& Nikolaeva, 2020, 22 May).

In other jurisdictions, courts have determined that contaminations from viruses are enough to constitute evidence of a property unfit for its intended use and as such having suffered the physical loss which is the needed element for business interruption insurance cover to operate (Pineau \& Nikolaeva, 2020, 22 May).

The Paris AXA ruling was thought as potentially opening the door to a wave of similar litigation. The case was brought by Stephane Manigold, who owns four Paris restaurants. He filed a lawsuit demanding AXA cover his operating losses after a government order in mid-March 2020 to close bars and restaurants to slow the spread of the coronavirus. The court said the administrative decision to close the restaurant qualified for insurance cover as a business interruption loss. Whatever the outcome in AXA's court case, prolonged legal wrangling might prompt the French insurance regulator to insist insurers put aside additional reserves to offset legal risk. However, such a course of action would impact insurers' profitability this year and in the years ahead (Pineau \& Nikolaeva, 2020, 22 May) AXA, following the Paris judgment 
and although it has appealed, stated said it will seek to meet the bulk of business interruption claims from some restaurant owners in France.

In the USA, the case law has developed both ways. In Mastellone v. Lightning Rod Mut. Ins. Co. ${ }^{16}$ (Pineau \& Nikolaeva, 2020, 22 May), an Ohio court found that mold did not constitute physical damage to property and thus did not trigger coverage under the policy. The court was of the opinion that whether a homeowner policy that triggered only, if a loss is a physical loss to property was activated when an undeniable presence of mold existed. The court found that the mold did not constitute physical injury because it did not affect the structural integrity of the property and because the mold could be removed without causing any harm to the property. The court concluded that absent any specific alteration of the property the assured failed to show that their house suffered any direct physical injury as required by the policy.

Universal Image Productions, Inc. v. Chubb Corp. ${ }^{17}$ is another case coming from courts requiring tangible damage to property in order to trigger policies that require direct physical loss or damage.

In Universal Image Productions, Inc. v. Chubb Corp. ${ }^{18}$, the insured sought coverage relating to water that seeped into the building and subsequently created a pervasive odor, mold, and bacterial contamination (both visual and aerosolized). The insurer moved for summary judgment on the grounds that the damage from the water seepage was a direct physical loss under the policy. The court, after looking at split decisions across the country's various jurisdictions, found that the mold and other water related damages did not trigger coverage. The court determined that the policyholders would need to show that it suffered structural or tangible damage to the insured property" rather than rely on proof that it suffered such intangible harms as strong odors and the presence of mold and/or bacteria.

Under Mastellone v. Lightning Rod Mut. Ins. Co. ${ }^{19}$ and Universal Image Productions, Inc. v. Chubb Corp. ${ }^{20}$, it appears that COVID-19 existing in an insured property would not qualify as physical damage. However, other courts use a less strict standard, only requiring that the property's function be rendered useless.

In Gregory Packaging, Inc. v. Travelers Prop. Cas. Co. of Am. ${ }^{21}$ the mere presence of an unwanted substance was found able to trigger coverage for polices requiring direct physical loss or damage. 2012-CV-04418, 2014 WL 11770106 (D.N.J. June 11, 2014). The District Court in New Jersey held that ammonia that was released inside an insured's facility constituted direct physical loss of or damage to the insured's property, thus meeting the physical damage threshold. Physical damage is met under this standard primarily when property is rendered "unusable”. In determining whether Gregory Packaging's property experienced physical harm, the

16 Mastellone v. Lightning Rod Mut. Ins. Co., 884 N.E.2d 1130 (Oh. App. 2008).

17 Universal Image Productions, Inc. v. Chubb Corp. 703 F. Supp. 2d 705 (E.D. Mich. 2010)

18 Universal Image Productions, Inc. v. Chubb Corp. 703 F. Supp. 2d 705 (E.D. Mich. 2010).

19 Mastellone v. Lightning Rod Mut. Ins. Co., 884 N.E.2d 1130 (Oh. App. 2008).

20 Universal Image Productions, Inc. v. Chubb Corp. 703 F. Supp. 2d 705 (E.D. Mich. 2010).

21 Gregory Packaging, Inc. v. Travelers Prop. Cas. Co. of Am. 2012-CV-04418, 2014 WL 11770106 (D.N.J. June 11, 2014) 
court looked to various cases holding that direct physical loss arises when property is rendered unusable . $^{22}$.

Gregory Packaging, Inc. v. Travelers Prop. Cas. Co. of $\mathrm{Am}^{23}$, the cases it cites, and other cases containing similar reasoning may arm claimants with a more liberal definition of "physical damage", but even this standard may not provide a silver bullet to the physical damage threshold found in most policies. Of particular note is that Physical damage is met under this looser standard primarily when property is rendered "unusable". It is not readily observable that all policyholders can meet this requirement. Many properties are operating in limited capacities, but they are not unusable. This will be an issue that courts, like in Gregory Packaging, Inc. v. Travelers Prop. Cas. Co. of Am. ${ }^{24}$ will need to address. What the case law makes clear is that regardless of the jurisdiction, there will be substantial resources dedicated to the battle of whether COVID-19 constitutes physical loss. Legal conclusions regarding what constitutes physical damage are difficult. Claimants will likely have to show not only that COVID-19 is considered physical damage, but that it caused physical damage to their property in particular (Nicholson \& Craig, 2020, 8 April).

Companies in the United States continue to file business interruption lawsuits against their insurers for claims arising from state and local government shutdown orders in response to the COVID-19 pandemic. At least 1,250 cases have been filed nationally, up to the end of October 2020 and these cases have been filed in both state and federal court and in every state. While the weekly rate of new cases has declined, there are still historic numbers of cases being filed every month.

Over a third of these cases have been filed by restaurants and bars. Similarly, slightly less than a third of the cases have been filed as class actions, with a similar amount of cases containing bad faith claims. Of cases where courts have ruled, the nationwide trend is in favor of insurers. Nearly $75 \%$ of cases have resulted in dismissals of the policyholder's claims. However, two opinions in New Jersey and North Carolina, have found in favor of the policyholder.

In Optical Services USA/JCI v. Franklin Mutual Insurance Co. ${ }^{25}$, heard in Superior Court of New Jersey, Law Division, Bergen County, the court ruled that physical loss or physical damage was not required under New Jersey law. Similarly, in North State Deli LLC et al. v. The Cincinnati Insurance Co. et al. ${ }^{26}$, heard in the Superior Court for the County of Durham, the

22 See, e.g. Wakefern Food Corp. v. Liberty Mut. Fire Ins. Co., 968 A.2d 724, 727 (N.J. Super. Ct. App .Div. 2009) (holding that an electric grid was "physically damaged" because of "the loss of function of the system as a whole"); Western Fire Ins. Co. v. First Presbyterian Church, 437 P.2d 52 (Colo. 1968) (holding that the saturation of a church with gasoline vapors constituted "direct physical loss" because the building was no longer usable); Port Auth. of New York E'New Jersey v. Affiliated FM Ins. Co., 311 F.3d 226, 236 (3d Cir. 2002) (holding that "[w] hen the presence of large quantities of asbestos in the air of a building is such as to make the structure uninhabitable and unusable, then there has been" physical damage); Nicholson \& Craig (2020, 8 April).

23 Gregory Packaging, Inc. v. Travelers Prop. Cas. Co. of Am. 2012-CV-04418, 2014 WL 11770106 (D.N.J. June 11, 2014).

24 Gregory Packaging, Inc. v. Travelers Prop. Cas. Co. of Am. 2012-CV-04418, 2014 WL 11770106 (D.N.J. June 11, 2014).

25 Optical Services USA/JCI v. Franklin Mutual Insurance Co., No. BER-L-3681-20.

26 North State Deli LLC et al. v. The Cincinnati Insurance Co. et al.; 20-CVS-02569. 
court granted summary judgment in favor of the policyholder restaurants, concluding that physical damage to the building was not required under the policy at issue (Keane \& Reich, 2020, 26 October).

\subsection{COVID-19 insurance litigation analysis}

By early October 2020, over 1,250 lawsuits against insurers have been filed in the United States since the pandemic began. The rate of filings has dropped; while in late August an average of 45-50 were being filed each week, that rate has dropped to 15-20 cases per week. To put these case numbers and filing rates into perspective, the typical "large" hurricane will result in 100 or less business interruption cases being filed within the first year. Superstorm Sandy in 2012 resulted in approximately 150 business interruption cases being filed within the first year. Based on the amount of litigation COVID-19 is creating, it is the equivalent of a major hurricane making landfall every month ${ }^{27}$. These cases have been filed in state court and federal court, as individual claims and class actions, and one-quarter of the cases involve claims for insurance bad faith, which can result in the imposition of treble damages or punitive damages against the insurer. More than one-quarter of the cases have been filed as class actions. Further, a greater percentage of cases filed now contain bad faith claims, as compared to earlier filed cases. It is noticeable that early motions practice has led to many dismissals.

On July 2, 2020, a state court in Michigan ruled in favor of the insurers in Gavrilides Management Company, et al. v. Michigan Ins. Co. ${ }^{28}$. This appears to be the first substantive ruling on COVID-19 issues in the country. The insured argued that the virus exclusion did not apply because the loss of access was caused by the government orders, not by the virus. In addition, the insured argued that the loss of use of the property caused by the governmental orders constituted "direct physical loss" within the meaning of the policy. Applying Michigan law, the court rejected two arguments from the policyholder: (1) that the loss of use of their property as a result of government closure orders was a "direct physical loss" and (2) that the virus exclusion in the policy did not apply (Ross, Montgomery, \& Laws, 2020).

Michigan Insurance argued that neither the facts nor the law supports the Plaintiffs' arguments because: (1) there must be a direct physical loss that alters "the structural integrity of the property in order to trigger coverage", and (2) that "the virus exclusion of the policy [...] will not pay for loss or damage caused by or resulting from any virus, bacterium, or other microorganism that induces or is capable of inducing physical distress, illness, or disease".

The Court found that coverage under Gavrilides' policy applied only to "actual loss of business income sustained during a suspension of operations". The Court went on to hold that the suspension of business operation must be caused by "direct physical loss of or damage to

27 These lawsuits typically seek payments under either business interruption or civil authority coverage in connection with COVID-19. Some only seek a declaratory judgment, most articulate a breach of contract claim, and some include claims for bad faith insurance practices. Generally, the allegations articulate claims that government ordered closure (from either the state or local government) or changing consumer preferences (stemming from the pandemic) and disrupted supply chains obligate the insurers to provide coverage, either as a result of the civil authority provisions in the policy or the lack of a specific virus exclusion (Keane \& Reich, 2020, 26 October).

28 Gavrilides Management Co., LLC v. Michigan Ins. Co., Case No. 20-000258-CB, (Ingham Cty Circuit Court, 7-1-20). 
property". The Court agreed with both of the arguments proffered by Michigan Insurance, and found that direct physical loss must be "something that is tangible [...] that alters the physical integrity of the property" and that business interruption claims for loss of the use of property are not recoverable under a policy that only covers direct physical loss or damage. Thus, the Court determined that Gavrilides' claim was barred because no direct physical loss was alleged or sustained, and that the Plaintiff's claim was barred by the insurance policy's virus exclusion. As a result, the Court granted Michigan Insurance's Motion for Summary Disposition and dismissed the Plaintiff's Complaint, with prejudice (Ross, Montgomery \& Laws, 2020). In a bench ruling, the Ingham County judge concluded that "direct physical loss or damage" requires more than mere loss of use or access, and that the virus exclusion was unambiguous and excluded coverage (Keane \& Reich, 2020, 26 October).

The majority of cases where the defendant insurer has responded with a Rule 12 motion to dismiss based on the pleadings have resulted in an early win for insurers. As a result, insurer exposure to these cases has been minimal. However as time went by policyholder arguments have started gaining traction. Some policyholders have started to develop novel arguments. Many CGL policies issued in the United States since the original SARS and Ebola pandemics now contain a virus exclusion. At least one lawsuit has been filed to directly test the strength of the ISO “CP 01400706 " virus exclusion" ${ }^{29}$. Litigation has also revealed that some businesses in the United States have policies which contain an express endorsement which was added to the policies and, arguably, provide COVID-19 pandemic coverage.

In SCGM v. Lloyds of London ${ }^{30}$ a theater/restaurant company has sued Lloyds of London, based on a Lloyds policy which contains a "Pandemic Event Endorsement". Lloyd's has taken the position that COVID-19 is not "[...] covered under the Pandemic Event Endorsement as it is not a named disease on that endorsement". Other documents from the case indicate that the endorsement at issue provides coverage for at least twenty-five (25) diseases, including avian flu, zika, and "Severe Acute Respiratory Syndrome-associated Coronavirus (SARS$\mathrm{CoV}$ ) disease”. It is unknown how widely the Lloyds policy was sold, or what other companies may have purchased the pandemic event endorsement.

In August 2020, a federal judge in the Western District of Missouri ruled in favor of a group of hair salons and restaurants, by concluding that allegations of the presence of physical particles of the COVID-19 virus within their businesses satisfied the requirement for physical loss or damage under their insurance policies ${ }^{31}$. In October 2020, a New Jersey court ruled that the presence of physical particles of COVID-19 was not required under New Jersey law to state a claim for business interruption coverage. This has been the most significant ruling in favor of policyholders anywhere in the U.S., and this case will be cited by the policyholder bar in all jurisdictions going forward. In Optical Services USA/JCI v. Franklin Mutual Insurance

29 S.A.M.T. Inc. d/bla Town and Country v. Berkshire Hathaway, Inc., No. 20-2025 (W.D. Pa. June 11, 2020) alleges that because of regulatory estoppel - an equitable doctrine that prevents insurers from asserting an interpretation in court which is contrary to the insurer's original explanation of the policy when it obtained state regulatory approval of the policy — the virus exclusion does not apply; Keane \& Reich (2020, 26 October).

30 SCGM v. Lloyds of London No. 17-1137 (2d Cir. 2018). 
$\mathrm{Co}^{32}$, the policyholders presented straightforward business interruption and civil authority claims. The insurer responded that there had been no direct physical loss or damage, resulting in no coverage.

The plaintiffs argued two main bases for coverage being triggered under their policies. First, that the mere presence of a dangerous condition can constitute physical loss, citing Gregory Packaging Inc. v. Travelers Property Casualty Co. of America $^{33}$ where a federal court in New Jersey concluded that an ammonia gas discharge into a building rendered the air (and the entire building) "temporarily unfit for occupancy" and thus constituted direct physical loss or damage and Wakefern Food Corp. v. Liberty Mutual Fire Insurance Co. ${ }^{34}$, which found a grocery store had business interruption coverage for an electrical outage because the electrical grid and transmission lines were not capable of performing their essential function of providing electricity. In reliance on Wakefern ${ }^{35}$, the Optical Services ${ }^{36}$ court concluded that the word "physical" in an insurance policy should be construed more broadly than just "material alteration or damage". Optical Services ${ }^{37}$ finds the potential for coverage for a loss of use to a property, even without any tangible damage to property.

In addition, a group of North Carolina restaurants became the first policyholders in the country to obtain a judgment in their favor on their business interruption claims. In North State Deli LLC et al. v. The Cincinnati Insurance Co. et al. ${ }^{38}$ in granting partial summary judgment in favor of the policyholders (on their declaratory judgment claim), Judge Orlando Hudson focused on dictionary definitions of "physical" and "loss" and applied North Carolina common law (which is similar to many states) that various terms in a policy are to be construed harmoniously and that ambiguous terms are to be construed against the insurer. Specifically, Judge Hudson focused on the phrase "accidental physical loss or accidental physical damage".

Here, the policies provide coverage for "accidental physical loss or accidental physical damage". Cincinnati's argument that the policies require physical alteration conflates "physical loss" and "physical damage". The use of the conjunction "or" means-at the very least-that a reasonable insured could understand the terms "physical loss" and "physical damage" to have distinct and separate meanings. The term "physical damage" reasonably requires alteration to property. Under Cincinnati's argument, however, if "physical loss" also requires structural alteration to property, then the term "physical damage" would be rendered meaningless. But

32 Optical Services USA/JCI v. Franklin Mutual Insurance Co., No. BER-L-3681-20, Superior Court of New Jersey, Law Division, Bergen County.

33 Gregory Packaging Inc. v. Travelers Property Casualty Co. of America, 2014 U.S. Dist. LEXIS 165232 (D.N.J. Nov. 25, 2014.

34 Wakefern Food Corp. v. Liberty Mutual Fire Insurance Co., 406 N.J. Super. 524 (App. Div. 2009).

35 Wakefern Food Corp. v. Liberty Mutual Fire Insurance Co., 406 N.J. Super. 524 (App. Div. 2009).

36 Optical Services USA/JCI v. Franklin Mutual Insurance Co., No. BER-L-3681-20, Superior Court of New Jersey, Law Division, Bergen County.

37 Optical Services USA/JCI v. Franklin Mutual Insurance Co., No. BER-L-3681-20, Superior Court of New Jersey, Law Division, Bergen County.

38 North State Deli LLC et al. v. The Cincinnati Insurance Co. et al.; 20-CVS-02569, Superior Court for the County of Durham. 
the Court must give meaning to both terms. After arriving at this conclusion, Judge Hudson concluded that the policyholder's inability to access and use their facilities constituted a "physical loss" under the policies. He also concluded that the "Ordinance or Law", "Acts or Decisions", and "Delay or Loss of Use" exclusions did not apply. He then entered judgement in favor of the restaurants; the first judgment in favor of any policyholders on a business interruption claim in the United States and even if this ruling has been certified for immediate appeal, it will undoubtedly be cited to by policyholders across the country and presented to courts in other jurisdictions in support of arguments in favor of coverage (Keane \& Reich, 2020, 26 October).

\section{General Liability Insurance}

General liability insurance typically provides coverage against third party claims of property damage or bodily injury and the third party will have to show that he contracted the virus of COVID-19 as a result of an act or omission such as, e.g., not implementing measures to prevent further spread, although the danger of the spread of the virus has been communicated. In addition, general liability insurance coverage also includes coverage for government-mandated shutdowns and any related expenses. Service providers may also face large scale liability claims from the public on the allegation that their negligence towards the spread of the virus has cause infections from COVID-19 or even death. Even if some fungi and bacteria exclusions exist, as COVID-19 is a virus, such exclusions might not operate. General liability insurance typically provides insurance cover to medical professionals and hospitals who might face claims for negligence in observing isolation measures to avoid spreading the virus (FC\&S Expert Coverage Interpretation, 2020, $18 \mathrm{March}$ ). The claimants need prove that the liability arises as a result of their due to the occurrence of a covered risk, such as e.g. government-mandated closure. As insurers will often challenge the need to satisfy claims from disasters (natural or non-natural) on the basis that, as per their view, very few customers or clients are frequenting the premises of the claimant, therefore claimant policyholders will have to prove the projected losses as per the previous years' financial statements to be provided as evidence in court (French, 2014, p. 461). Some courts consider the historical financial data of the policyholder when calculating business interruption losses ${ }^{39}$, whilst other courts consider also local postcatastrophe economic conditions.

The rise in claims as a result of the pandemic might instigate the insertion of exclusions. Insurers may also attempt to invoke other exclusions - such as the pollution exclusion. No matter what the exclusions invoked may be, if they be named in detail they may grant the insurer an exclusion from covering certain risks and losses. On their part the assured will need to verify if policy exclusions apply to their own facts and circumstances.

Is our exposure to the COVID-19 virus an element of widespread contamination and a classification of the risk as catastrophic? As exposure to the virus has to be established, courts should implement the approach of proportional recovery to all victims. Like the asbestos cas-

39 Catlin Syndicate Ltd.v Imperial Palace of Miss., Inc., [2010] 600 F.3d 511, 516 (5th Cir.); Finger Furniture Co. $v$ Commonwealth Ins. Co., [2005] 404 F.3d 312, 314 (5th Cir.); Prudential LMI Commercial Ins. Co. $v$ Colleton Enters., Inc., [1992] No. 91-1757, 1992 WL 252507, (4th Cir.); Am. Auto. Ins. Co. v Fisherman's Paradise Boats, [1994] Inc., No. 93-2349CIVGRAHAM, 1994 WL 1720238. 
es, another environmental impairment forming another form of environmental contamination, calls for government schemes for mass catastrophic disasters, and other actions such as establishing a special victim's compensation fund.

\section{Catastrophic risks}

In the case of catastrophic risks, it is important to have the capacity to compensate as many victims as possible, and for this to be feasible in practical terms, a threshold need be in place, i.e. it is necessary to limit the class of victims to those with the most catastrophic losses. The unavailability of full compensation does not mean that all compensation should be denied. Government schemes in place are able to augment the pool of policyholders able to be compensated in case of catastrophic risks. In the light of the occurrence of COVID-19, various governments enacted legislative compensation mechanisms to help the insurance industry spread the risk and be able to respond to it, and the society to continue to operate.

Potential environmental exposures of contamination from the COVID-19 virus have forecast a considerable scale of potential losses for the assured. The principle of liability for environmental risks is a principle based on many law texts, and case law and reflecting the growing power of the judge, who is increasingly detached from the mere interpretation of the textual law rule in favour of the recognition of more and more principles. Judges use the soft law and attach either to international custom, or to an international treaty, or to a jurisprudential principle such as the duty of care in common law countries, or to a law in continental law countries such as the provisions of the civil code on the law of liability (Lhuilier, 2020, pp. 27-28).

Environmental insurance products may be designed to include affirmative cleanup, disinfection and decontamination coverage as a result of, among other things, a discharge, dispersal, release or escape of bacteria and viruses. Under pollution policies, disinfection expenses are specifically defined, and coverage is only provided for the properties which are scheduled to an insurance policy. Some policies contain a specific exclusion for disinfection expenses associated with communicable diseases (i.e., diseases transmitted via human-to-human contact). Such policy language may preclude coverage for COVID-19 but usually policies will affirmatively provide for disinfection or decontamination costs arising from viruses irrespective of how those viruses are communicated. Even in those circumstances where such disinfection/decontamination coverage may be available, policyholders should be aware that there may be unique and specific triggers including written reporting requirements to the local regulatory authorities as well as to the insurance company — often within a defined period (often 72 hours or less) of the discovery and/or reporting to regulatory authorities. The availability of other coverage such as crisis management (to restore reputational injury as well as evacuation expenses) or business interruption expenses will depend upon the breadth (or limitation) of what falls within a triggering pollution condition or other defined term under the policy (Rupprecht, 2020, 26 March).

Continental judges as seen in case law such as the Erika environmental disaster, adhere and in a sense attach to the civil liability also the due diligence rules which are becoming increasingly oriented towards environmental issues, and which have resulted in an increase in ethical commitments going beyond legal requirements, and also extend the companies' civil liability. The common law judge uses soft law to apply the duty of care case law principle and characterise the parent company's personal fault. Applying this to the current pandemic situation we see 
that by analogy case law such as the 2000 Lubbe $v$ Cape plc ${ }^{40}$ case, whereby South African workers complained that the British parent company had not taken any action to reduce the risks associated with mining employees of its South African subsidiary, and where as this was characterised as a breach of a duty of care under which the employer is required to provide a safe and healthy working environment for its employees and reasonable security for third parties within its "sphere of influence" and the Chandler $v$ Cape Plc ${ }^{41}$ case in 2012, where the English Court of Appeal made it clear that the parent company has a duty of care towards the employees of its subsidiary, and where the court used a test to demonstrate the existence of a duty of care, the "good neighbor" test, as per which the criterion of "foreseeability of damage", the close relationship existing, equity, reasonableness of such an "obligation", were employed, denote a widening of the scope for civil liability (Luhilier, 2020, pp. 27-32). Insurance claims will be affected and rely on such rulings.

The London market has tried to respond by putting in place excess liability limits available and catastrophic, high excess limits available and such coverage is usually effected via endorsement to the general casualty policy for pollution events, or by offering extensive environmental liability offering in the guise of environmental impairment liability insurance (EIL) with such policies being also able to respond to regulatory obligations (Sutherland, 2015). That said, full insurance coverage probably will never be available, for some risks are non-insurable and because insurance coverage will be more limited if liability due to the fact that it is limited to sudden and accidental incidents and based on certain exclusions therefore insurance coverage provided by the insurance market will not necessarily be the same, as full coverage for all potential liability. Policy makers should solicit for the creation of industry-wide pooling by providing high standards of safety regulation to facilitate mutual monitoring by operators and encourage pooling arrangements (Sutherland, 2015).

\section{The UK FCA Test Case}

To dissolve uncertainty a test case brought by regulator the Financial Conduct Authority (FCA) in court. Many UK policyholders whose businesses suffered losses during COVID-19 pandemic have received a welcome boost from the country's High Court. In mid-September the Court ruled that most "disease" clauses in business' insurance policies cover losses caused by a notifiable or infectious disease, in a test case brought by regulator the Financial Conduct Authority (FCA). However, the Court found that only some "denial of access" policies which involve losses caused by government actions, advice or restrictions in response to a disease rather than losses caused by the disease itself — provide cover. As a result of the judgment, it will be easier for "disease" policyholders to demonstrate that they should be covered for their losses as they will not need to point to specific local outbreaks as the cause of their losses.

The UK judgment is likely to be highly persuasive in other jurisdictions, particularly common law jurisdictions such as Hong Kong and Australia. However "denial of access" might mean that policyholders may find it more difficult to establish cover, as they must show the governmental action or advice was in response to a COVID-19 outbreak within a specified ra-

40 Lubbe v Cape Plc [2000] UKHL 41. 
dius. After examining a representative sample of policy wordings issued by eight insurers, the Court also clarified that the COVID-19 pandemic and the government and public response were a single cause of the covered loss - a key requirement for claims to be paid even if the policy provides cover. This is not a blanket success, as the Court did not find in favour of policyholders across all policy wordings. Hence, the judgment is a stark reminder of the vital importance of policy wordings. There are potentially wider implications for insurers and policyholders and whilst the judgment does provide some clarity, it also left issues to be resolved. The judgment doesn't specify how much is payable under each individual policy and provides no basis on which insurers are making monetary decisions. Nevertheless, the FCA has called for insurers to handle and assess business interruption insurance claims promptly and fairly when they have accepted liability. The High Court's decision on 15 September 2020 found that the majority of the 21 policy wordings should be interpreted in favour of policyholders. This potentially paved the way for payouts to an estimated 370,000 small businesses forced to close during lockdown. However, following that decision, six of the eight insurers whose policy wordings were considered applied for permission to appeal as did the FCA. The High Court allowed an appeal of the test case to "leapfrog" to the Supreme Court, although insurers Ecclesiastical and Zurich have opted not to appeal. The FCA's appeal is focused on the socalled trends clauses, aspects of the prevention of access wordings, and certain disease wordings where, exceptionally, the High Court limited cover under some policies to local-only outbreaks of COVID-19. The insurers' appeal is also concerned with the disease and prevention of access clauses found in the business interruption sections of policies (Trevelyan, 2020, 13 October).

The FCA is appealing the High Court's ruling on trends clauses which appear to allow an insurer to reduce the indemnity payable by taking into account as a trend, a reduction in revenue caused by one element of what the court referred to as a "composite" peril occurring before the policy is triggered by another element of the composite peril. In addition, the FCA is appealing the High Court's ruling on Hybrid and Prevention of Access Clauses, specifically its assessment that references to "restrictions imposed", "closure or restrictions" and "enforced closure" require government actions to have mandatory legal force and would not be satisfied by the instructions or advice of a competent authority. In the FCA's view, the High Court's analysis gave "an uncommercially and over-formalistically narrow scope to these clauses".

The FCA is also challenging further declarations about Hybrid and Prevention of Access Clauses, under which the court found that terms such as "prevention", "denial of access", "interruption" or "inability to use" required total closure of premises or an almost total inability to use and would not be satisfied by partial closure.

Four insurers, Argenta, MS Amlin, QBE and RSA, have filed applications for permission to appeal the High Court's ruling that occurrences of COVID-19 within the relevant policy area formed "part of one indivisible cause" that was indistinguishable from the national outbreak as a whole. Argenta, MS Amlin, Hiscox and RSA also sought permission to appeal the court's finding that the decision in leading case Orient Express Hotels Ltd -v-Assicurazioni General $\mathrm{SpA}^{42}$ should not be followed. The same insurers sought permission to appeal the interpretation of so-called counterfactuals. These are hypothetical models used to assess the extent to which a business may or may not have been affected. In addition to the above, certain insurers

42 Orient Express Hotels Ltd-v-Assicurazioni General SpA [2010] Lloyd's Rep I.R. 531. 
have also sought permission to appeal against the High Court's findings in relation to their specific policy wordings. These include so-called hybrid clauses which refer to both restrictions relating to premises and the presence of a notifiable diseases within the vicinity of the insured premises.

Much of the High Court analysis hinges on the Orient Express Hotels Ltd - v-Assicurazioni General SpA ${ }^{43}$ case where the Orient Express Hotel in New Orleans claimed against its business interruption policy following storm damage arising from Hurricane Katrina, which resulted in the closure of the hotel for two months in 2005. The High Court and Court of Appeal concluded that the hotel would have suffered business losses even if it had not been damaged as the city in which it was based was forced to shut down following the hurricane. As a result, the hotel was treated as if it had been an undamaged hotel in a damaged city. On that basis, the hotel recovered only a limited amount under its policy, rather than the $\$ 2.15 \mathrm{~m}$ indemnity it sought. Lawyers for the insurers in the FCA test case have argued in favour of a similar analysis for policyholders whose businesses were hit by COVID-19. However, in the FCA test case, the judges, Lord Justice Flaux and Mr. Justice Butcher concluded that the Orient Express analysis was of no relevance to the test case, adding that they would have ruled that it was wrongly decided if they had been forced to consider it. Such a construction is more sympathetic to policyholders and paves the way for more generous payouts under so-called trends clauses which assess the extent to which a business has been financially affected by an event by reference to its trade during that period (Millar \& Brown, 2020, 5 November).

On $15^{\text {th }}$ January 2021, the Supreme Court delivered its judgment in the FCA's business interruption insurance test case. On the FCA's argument for policyholders that the 'disease' and 'prevention of access' clauses in the representative sample of 21 policy types provide cover in the circumstances of the COVID-19 pandemic, and that the trigger for cover caused policyholders' losses, on the FCA's appeal, the Supreme Court ruled that cover may be available for partial closure of premises (as well as full closure) and for mandatory closure orders that were not legally binding; that valid claims should not be reduced because the loss would have resulted in any event from the pandemic; and that two additional policy types from insurer QBE provide cover. Hence, the Supreme Court, by substantially allowing the FCA's appeal on behalf of policyholders, not only completes the legal process for impacted policies but also relays the message that the many thousands of policyholders will now have their claims for coronavirus-related business interruption losses paid ${ }^{44}$.

\section{Conclusions}

The legal landscape for insurance coverage for losses due to the COVID-19 pandemic is continuing to shape as the phases of the pandemic recur. As governments intermittently impose measures insurance claims continue to be submitted be it for business interruption policies or general liability or environmental impairment losses coverage. Many "standard" policies forms may contain exclusions for viruses, others will not. The uncertainties surrounding lia-

43 Orient Express Hotels Ltd -v-Assicurazioni General SpA [2010] Lloyd’s Rep I.R. 531.

44 https://www.fca.org.uk/news/press-releases/supreme-court-judgment-business-interruption-insurance-testcase accessed 19.1.2021. 
bility for COVID-19 makes these claims and policy renewals as well as policy renewal negotiations even more challenging.

Case law has evolved in actually accepting the need for compensation and the recognition of force-majeure occurrences, as well as the physical damage to the property or persons. However, the attitude of the courts differs per case and jurisdictions and this is case law evolving alongside the pandemic per se. Hence, it is a mater to yet see how it shapes. In the USA, the courts have started allowing such claims to flourish and have started granting policyholders judgments in their favour. In Europe the situation is disperse but the general trend is to accept and satisfy COVID-19 law suits as business interruption is found as causally linked to the claim. In the UK, the FCA test case has shown an eagerness to set standards to avoid a market collapse as well as to serve both insured and policyholder fairly.

The recent UK Supreme Court's ruling on appeal of the FCA test case entails that more policyholders will have valid claims and some pay-outs will be higher ${ }^{45}$.

As the world continues to address COVID-19 as a pandemic, an important aspect of managing the response to COVID-19 includes a comprehensive review of insurance. The industry needs also lobby so that legislative compensation mechanisms set up by governments apart, the creation of pools is effected to be able to allow the private insurers to better respond to the risks and claims and provide adequate insurance coverage. Common law liability is also a mechanism to which parties resort as more holistic compensation mechanisms are needed.

\section{References}

FC\&S Expert Coverage Interpretation (2020, March 18). ISO provides business interruption endorsement in response to coronavirus, Nuco. Retrieved from: https://www.nuco.com/fcs/2020/03/18/iso-provides-business-interruptionendorsement-in-response-to-coronavirus/ (last accessed 27/11/2020)

French, C. (2014). The Aftermath of Catastrophes: Valuing Business Interruption Insurance Losses. Georgia State University Law Review, 30(2), 461-520. doi: 10.2139/ssrn.2203695.

Goode, R. (1998). Commercial Law in the Next Millenium. London: Sweet \& Maxwell.

Hewitson, R. (2020). Force Majeure, Frustration and Contracts. The Conveyance and Property Lawyer, 2020(2), 116-123.

Iijima, K. (1994). Recission and Adjustment of Contracts as Effects of the Doctrine of Changed Circumstances. Toritsudai Hogakkai Zasshi, 35.

Irvine, M. (2020). Force majeure clauses and the coronavirus. Ent. Law Review, 31(5), 155-157.

Keane, R., \& Reich, J. (2020, October 26). COVID-19 Shutdowns, Related Litigation Put Pressure on Business Interruption Insurers. Womble Bond Dickinson. Retrieved from: https://www.womblebonddickinson.com/us/insights/alerts/covid-19-

45 https://www.fca.org.uk/news/press-releases/supreme-court-judgment-business-interruption-insurance-testcase accessed 19.1.2021. 
shutdowns-related-litigation-put-pressure-business-interruption-insurers (last accessed $21 / 11 / 2020)$

Lhuilier, G. (2020). The new liability of transnational companies for environmental risks. International Business Law Journal, 1, 25-45.

Millar, C., \& Brown, M. (2020, November 5). Business Interruption insurance test case: both sides to appeal to the Supreme Court. Retrieved from: https://www.penningtonslaw.com/news-publications/latest-news/2020/business-interruption-insurance-test-case-both-sides-to-appeal-to-the-supreme-court (last accessed 21/11/2020)

Nicholson, B., \& Craig, P. (2020, April 8). COVID-19 and business interruption claims: The looming US battle ahead. Norton Rose Fulbright. Retrieved from: https://www.nortonrosefulbright.com/en/knowledge/publications/96a8191e/ covid-19-and-business-interruption-claims-the-looming-us-battle-ahead (last accessed $21 / 11 / 2020)$

Nottage, L. (2007). Changing Contract Lenses: Unexpected Supervening Events in English, New Zealand, U.S., Japanese, and International Sales Law and Practice. Indiana Journal of Global Legal Studies, 14(2), 385-418.

Pineau, E., \& Nikolaeva, M. (2020, May 22). Insurer AXA must pay restaurant's COVID-19 losses, French court rules. Reuters. Retrieved from: https://www.reuters.com/article/ushealth-coronavirus-insurance-axa-idUSKBN22Y2LR (last accessed 21/11/2020)

Ross, R., Montgomery, D., \& Laws, D. (2020). MI Circuit Court Grants Summary Judgment for Insurer, Denies COVID-19 Business Interruption Claim. Retrieved from: https://midkifflaw.com/2020/08/michigan-circuit-court-grants-summary-judgment-for-insurer-denies-covid-19-business-interruption-claim/ (last accessed $21 / 11 / 2020)$

Rupprecht, D. (2020, March 26). Insurance Recovery for COVID-19. Smith LLP. Retrieved from: https://www.reedsmith.com/en/perspectives/2020/03/insurance-recovery-for-covid 19 (last accessed 27/11/2020)

Stathopoulos, M. (1998). Greek Law of Torts I. Athens: Sakkoulas.

Sutherland, S. (2015). Paying for Pollution? AIG. Insider Quarterly's, Winter Issue.

Trevelyan, L. (2020, October 13). Insurance: courts grapple with business interruption cases in wake of COVID-19 lockdowns. Retrieved from: https://www.ibanet.org/Article/NewDetail.aspx?ArticleUid=632D0F38-A252-40BB-B492-F65C219387B3 (last accessed 21/11/2020) 